\title{
Ayurveda Consideration of Abhishyanda and its Management: A Review
}

Available online at www.hjhs.co.in

\section{REVIEW ARTICLE}

\section{Ameetkumar Shamsunder Agrawal*,a, Suvarna P Golecha ${ }^{\text {b }}$}

${ }^{a}$ P.G. Scholar, Dept of Shalakya Tantra, S.V.N.H.T Ayurveda Mahavidyalaya, Rahuri, India.

${ }^{\mathrm{b}}$ Associate Professor, Dept of Shalakya Tantra, S.V.N.H.T Ayurveda Mahavidyalaya,

Rahuri, India.

DOI 10.22270/hjhs.v6i4.111

\begin{abstract}
Abhishyanda is considered as Sarvagata Netraroga which is a dreadful disease and possess symptoms of conjunctivitis as per the modern science. The inflammation of conjunctiva mainly occurs in Abhishyanda which can spread through Rakta. Abhishyanda if not cured then it can causes Adhimanth associated with acute pain. The other complication may includes Sandhigat roga, Shuklagat roga, Krishnagat roga and Vartmagat roga, etc. Abhishyanda is put as disease amongst the seventeen Sarvagat rogas. Ayurveda classics mentioned various types of Abhishyanda including Vataja Abhishyanda, Pittaja Abhishyanda, Kaphaja Abhishyanda and Raktaja Abhishyanda. The disease involves Kledana in Doshas and Dhatu due to which profuse discharge comes out from the eye. Therefore excessive discharge from eye is the major feature of Abhishyanda. Ayurveda described different approaches such as Anjana, Pariseka, Pralepa, Aschyotana, Tarpana, Sweda and Putpaka for the management of various Netraroga. Some ayurveda formulations and herbs also offers relieves in the symptoms of Abhishyanda.
\end{abstract}

Keywords: Ayurveda, Netraroga, Abhishyanda, Shalakya Tantra

\section{Introduction}

Conjunctivitis is condition of eye involving inflammation of conjunctiva mainly occurs due to the infection of the membrane. This condition causes irritation and discomfort, Ayurveda described conjunctivitis as Abhishyand. As per Ayurveda Abhishyand involve pathological changes in the Strotas leading to the congestion of vessels of the eye. The symptoms include Rag and Lohit Netrata, Sangharsh, Nistoda, Daha and Paka, etc.

The literal meaning of Abhishyanda is depicted in Figure 1, which indicates condition of profuse discharge. The excessive profuse discharge from eye is main feature of Abhishyanda which is a Sarvagata Netra Roga that affects all parts of the eye (1-5)

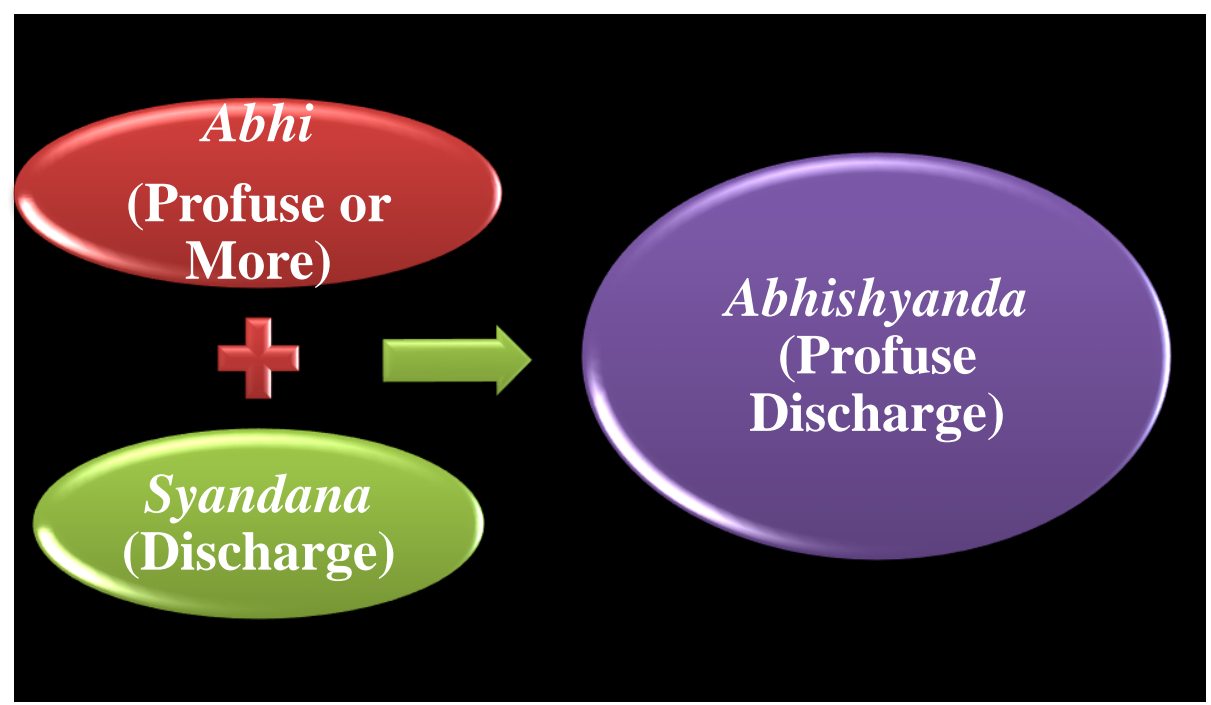

Figure 1. Ayurveda meaning of word Abhishyanda 
Conjunctival congestion, sensation, pricking sensation, burning sensation, and inflammation, etc. are common symptoms of conjunctivitis as per the modern science. Conjunctiva becomes reddish and inflamed in conjunctivitis which mostly seen in summer season. Eye drops, lubrication, ointment and antibiotics etc., are major therapeutic approaches for managing symptoms of conjunctivitis.

Symptoms as per modern science:

$>$ Redness in eyes

$>$ Itchiness in eyes

$>$ Irritation in eyes

$>$ Discharge in eyes

$>$ Difficulty to open eye in morning

$>$ Tearing and burning sensation, etc.

Causes:

$>$ Viral infection

$>$ Bacterial infection

$>$ Effects of allergens

$>$ Chemical splash in the eye

$>$ Foreign object

$>$ Blockage of tear duct especially in new born, etc.

Types of Abhishyanda:

Vataj Abhishyanda

Pittaj Abhishyanda

Kaphaj Abhishyanda

Raktaj Abhishyanda

Samprapti Ghataka:

* Dosha: Kapha Pradhana
Tridosha
\# Dushya: Rasaand Rakta
* Srotasa: Rasavaha and
Raktavaha Strota
\# Dushti: Sanga and
Atipravriti.

The etiological factors causes Sarva deha syandana leading to the Siro-abhisyanda which in later stage causes NetraAbhishyanda involving Khavaigunya associated with Acaksusya sevana. The major Dosha involve in condition is Kapha, while Rasa Dhatu along with Rasavaha Strota produces condition of Sanga and Atipravriti.

\section{Abhishyanda Chikitsa:}

Snigdh or ushna drugs used for Vataj abhishyanda, Mrudu and shitala therapy recommended for Pittaja abhishyanda while Tikshna, Ruksha and Vishada drugs advised for Kaphaja abhishyanda.

Snehan, Swedana, Anjana, Seka, Ruksha Aschyotan \& Ruksha Putpaka, etc. are useful for Kaphaj Abhishyanda. Local application of paste of drugs to eyelids externally, here drugs like Rasanjan, Shunthi, Vacha, Haridra and Murungi, etc. can be used for the purpose of local application in case of Abhishyanda.

Tikshna gandusha \& Nasya also advised when symptoms are manifested, Snehana with Ghee, Sneha virechana, Snehana nasya and Sirobasti, etc. also advocated to relives symptoms of Abhishyanda (6-10)

Oral administration of Sahacharadi ghruta or Taila

> Sneha Virechana of Tilwak ghruta with Tilwak kashay

> Sneha basti or Anuvasana basti to removes vitiated Doshas.

> Nasya with Shatavari, Dashmula, Balamula and Siddha Tail, etc.

$>$ Tarpana with Shriparni, Erand and Nagarmotha, etc.

$>$ Snehik putpaka also advised.

$>$ Ascyotana of goat's milk boiled with the bark of Tagara, Manjishta \& Hribera, etc.

$>$ Anjana formed due to the mixture of Haridra, Jeshtamadha and Haritaki, etc. with goat's milk.

$>$ Aanupves varena shiro vadana lepa is considered useful.

$>$ Saktu pindika is used for Vataj Abhishyanda.

$>$ Granny leaf paste relieves pain and swelling.

$>$ Chirchite paste reduces inflammation. 
$>$ Prajmoda juice when applied externally then helps in conjunctivitis.

$>$ Chandi milk provides soothing effect.

$>$ Rose-paste mixed with butter relieves symptoms of conjunctivitis.

$>$ Tulsi leaves helps to reduces inflammation.

$>$ Triphala Churna is considered good for spurring allergic inflammation and burning sensation.

$>$ Chandroyati Vati improves allergy resistance, thus can be advised for conjunctivitis.

\section{Conclusion}

Abhishyanda is Sarvagata Netraroga which affects eye in all ways and possess symptoms of conjunctivitis as per the modern science. The inflammation of conjunctiva leads profuse discharge from eye associated with other symptoms like; Lohit Netrata, Sangharsh, Nistoda, Daha and Paka, etc. Ayurveda mentioned various types of Abhishyanda i.e.; Vataja Abhishyanda, Pittaja Abhishyanda, Kaphaja Abhishyanda and Raktaja Abhishyanda. Ayurveda described different approaches such as Anjana, Pralepa, Aschyotana, Pariseka, Tarpana, Sweda and Putpaka, etc. for the management of various Netraroga. These Kriyakalpas offers several health benefits in case of Abhishanda and Kaphaghna Dravyas plays important role in Abhishanda Chikitsa since it is Kapha dominant condition. Eye drops, lubrication, ointment and antibiotics etc., are major therapeutic approaches for managing symptoms of conjunctivitis as per the modern science.

\section{Acknowledgements}

We would like to convey our sincere gratitude towards the HJHS Journal for publishing our article.

Financial Disclosure statement: The author received no specific funding for this work.
The authors declare that there is no conflict of interest regarding the publication of this article.

\section{References}

1. Dalhanacharya Shri. Commentator, Sushruta Samhita, Uttaratantra, Sarvagata Roga vigyaniyam Adhyaya. 12th ed. 5. Vol. 6. Varanasi: Chaukhamba Surbharati Prakashan; 2003. p. 26.

2. Ibidem Sushruta Samhita (1) Uttar Tantra, Sarvaroga Vigyaniyam, Adhyaya. 6(3-4):26.

3. Dhanda RP, Kalevar V. A text book of clinical ophthalmology. 4th ed. Delhi: Galgotia Publications; 1993.

4. Kumar Dileep. Role of Triphala eye drops in the management of Abhishyanda (conjunctivitis) Journal of Ayurveda. 2000;24:17-20.

5. Dr. Anantram Sharma : Sushruta Samhita, Sarvagata Roga Vijnaniyan. Choukhamba Surbharati Prakashan, Varanasi : Vol II : Reprint 2012 : Page no. 44-45.

6. Kaviraj Atridev Gupt : Ashtangsangrah, Sarvagakshi Roga Vidnyaniya, Adhyaya 18th . Choukhamba Publication. Varanasi : Page No. 251.

7. Vd. Shrilaxmipati Shastri : Yogaratnakar, Uttrarardha, Netraroga Chikitsa. Choukhamba Publication. Varanasi: Reprint 2012: Page No. 389.

8. Shraddha Ingle, To review management of kaphaj pratishyay with shweta sarshap lepa , Ayurlog: National Journal of Research in Ayurved Science: Vol 8 No 01 (2020): AYURLOG : NJ-RAS| January 2020.

9. Kumar Dileep. Role of Triphala eye drops in the management of Abhishyanda (conjunctivitis). Journal of Ayurveda 2000;24:17-20.

10. Vaishnava PU, A clinical study of Kriya Kalpa to assess its therapeutic efficacy in disease of eye w. s. r. to Abhishyanda (conjunctivitis), Journal of Ayurveda 1982;7:27-30

\section{Conflict of Interest}

